\title{
Workplace Spirituality: A Meta-theoretical Perspective
}

Herman J Pietersen

Professor, University of Limpopo, Turfloop Campus, Sovenga, 0727

Doi:10.5901/mjss.2014.v5n23p2269

\section{Abstract}

A meta-theory was developed that brought together implicit premises or world views that constantly re-surface in human thought. Although these elements, which are often referred to being the result of differences in human 'temperament', have long been part of the scholarly activity of humankind, a comprehensive synthesis has been lacking so far. In order to redress this shortcoming, an integrated perspective, supported by scholarly evidence, regarding basic characteristics of making sense of life and world was introduced. As a result, four paradigmatic or root intellectual orientations (designated as type I, type II, type III and type IV) have been identified. The theory was found to be applicable across a wide range of scholarly disciplines and cultures. In the present case the workplace spirituality literature is analyzed, using this framework. Four basic paradigms in the workplace spirituality scholarship are identified and briefly described in terms of a survey of a number of examples of each meta-type: the theoretical (type I), empirical (type II), narrative-interpretive (type III), and the pragmatic (type IV).

Keywords: Meta-theory, theoretical, empirical, narrative, pragmatic

\section{Introduction}

A meta-theory was developed that, in a coordinated manner, brought together axiomatic intellectual distinctions or world views that constantly re-surface in human thought.

The meta-theory was subsequently tested for its conceptual plausibility and evidentiary support across a wide range of scholarly disciplines, thinkers, topics and cultures. (Pietersen, 2011, 2014)

The present paper extends the application of the framework by showing that basic modalities of the mind also manifest themselves in the field of workplace spirituality. Figure 1 shows four orientations in human thought that are the result of a combination of two epistemological and two ontological stances, namely: objectivist-empyrean (type I); objectivist-empiricist (type II); subjectivist-empiricist (type III), and the subjectivist-empyrean (type IV). Figure 2 provides a description of characteristic elements of each of the basic modalities in human thought.

Figure 1: The four orientations in human thought

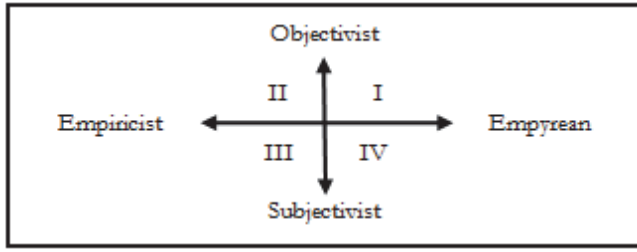

Figure 2: Characteristic elements of each of the basic modalities in human thought.

\begin{tabular}{|l|l|}
\hline Objectivist-Empiricist Orientation (type II) & Objectivist-Empyrean Orientation (type I) \\
Emphasize reason (rationality) & Emphasize reason (rationality) \\
Impersonal & Impersonal \\
Systematic-analytic & Theoretical/integrative \\
Dicroscopic focus & Macroscopic focus \\
Conced explanation & Comprehensive understanding \\
To systematically analyze, order, predict and & Concerned with possible ideas \\
control life/world & To penetrate the deepest essentials and mysteries \\
\end{tabular}




\begin{tabular}{|l|l|}
\hline Subjectivist-Empiricist Orientation (type III) & Subjectivist-Empyrean Orientation (type IV) \\
Personal-engaged & Emphasize values (humanism) \\
Poetic-particular-critical & Communal-engaged \\
'Feeling with' (solidarity) & Conceptual \\
Concerned with individuals (the particularized & 'Feeling for' (development, becoming) \\
other) & Concerned with society (the generalized other) \\
To praise, eulogize, tell inspiring stories or To & Society according to valued ideals \\
\hline
\end{tabular}

Figure 3: Four basic orientations in the workplace spirituality field

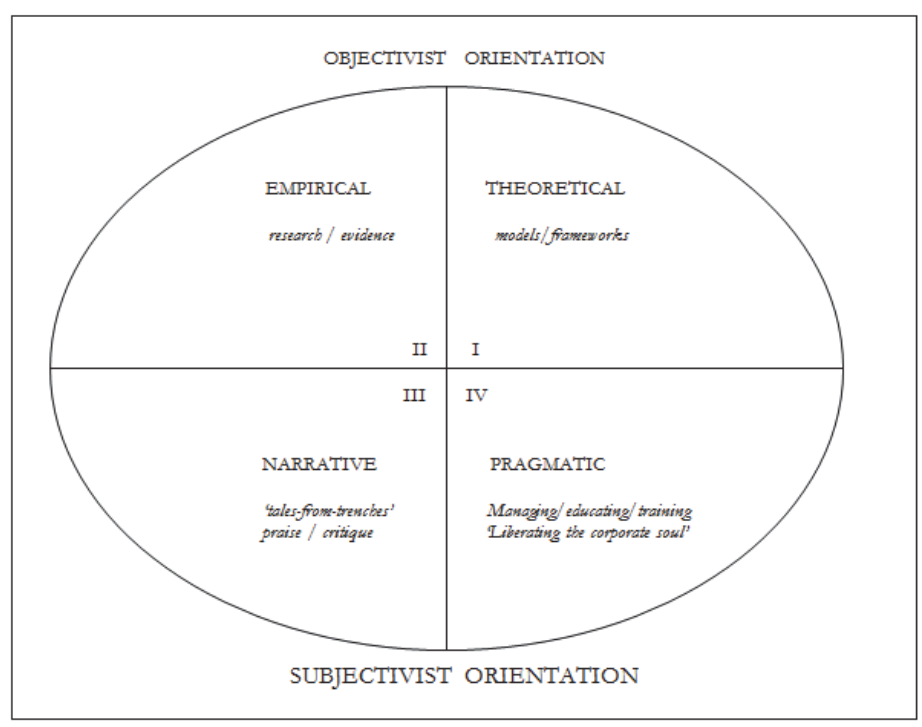

With the aid of the paradigmatic knowledge framework above, the workplace spirituality literature is examined with a view to contribute to an overall understanding of activities in the field, and to identify areas of further research. The discussion that follows will neither attempt a detailed commentary on publications in purely technical or methodological terms, nor a full-scale review of the workplace spirituality literature, as such. Instead, the focus will be on a broader conceptual analysis of the typical nature of current contributions to the field. Toward this end use will be made of the frameworks in Figures 1, 2 and 3.

\section{Workplace Spirituality: A Brief Overview}

For various reasons the topic of 'workplace spirituality' has achieved increasing prominence over the past few decades, especially in the popular press and bookstores, in management circles and among what can be referred to as 'corporate soul promoters', of varying persuasions. In view of the ongoing historical concern with human happiness or well-being, this should not come as a surprise. The importance to people of finding deeper meaning in their lives (also their working lives) and the concomitant obligation of management to take cognizance of their employees' needs in this regard, is also highlighted by Poe \& Courter (1995)

Several reasons for the rising interest in workplace spirituality are usually given (see (Inglehart, 1999), namely:

- widespread organizational downsizing, reengineering, outsourcing and layoffs;

- a shift toward the workplace as important source of community in lieu of the declining spiritual role of, and more tenuous connections with, external bodies such as the churches, civic and neighborhood groups;

- an interest in Eastern (as well as New Age) philosophies, especially those providing esoteric techniques for discovering one's spiritual center and sense of being a member of a 'universal community';

- the pressures of global economic competition; and, in general, the stresses of a Tofflerian world of constant change; and 
- the growing emphasis on having a meaningful life, in many countries, and a redirection (not decline) of spiritual needs, away from purely materialistic concerns.

A distinction is made between spirituality, religion and ethics in the workplace spirituality literature, although a: "...clear definition of the boundaries of spirituality has been elusive. (Garcia-Zamor, 2003: 255). Scholars and management mostly prefer to avoid 'religion' and to focus on ethics and spirituality, with ethics being defined as about the rules and principles of morally acceptable conduct, and spirituality as being about a universal, deeper, aspect of human nature. Definitions abound, but for the sake of brevity the approach of one author is provided here, namely, of spirituality: "... as the journey to find a sustainable, authentic, meaningful, holistic, and profound understanding of the existential self and its relationship/interconnectedness with the sacred and the transcendent. (Karakas, 2010: 91).

Various trends occur in terms of the type of issues and developments that are highlighted in the workplace spirituality movement:

- A decade ago it was estimated that there were about 4000 'corporate chaplains' in, or contracted to, organizations in the USA (Garcia-Zamor, 2003: 258);

- A general aim is: "...to make the area of spirituality at work research more legitimate and mainstream to organizational studies." (Karakas, 2010: 92);

- Problems concerning the incorporation of spirituality into the life of work organizations are, for instance, the dangers of: "... proselytism; of compatibility; of spirituality becoming a fad or a management tool to manipulate employees; and the legitimacy problem the field of spirituality at work faces in theory, research, and practice." (Karakas, 2010: 99);

- Although there is growing interest in, as well as much more empirical research, the field of workplace spirituality: "... is still characterized by a fragile position in organizational behaviour, low paradigmatic development, inadequate measurement scales and incipient empirical research." (Nicolae, 2013: 551);

- Main research issues in the field of workplace spirituality and spiritual leadership include: "...the conceptualization, definition, measurement and operationalization of the 'nebulous' concepts of workplace spirituality and spiritual leadership, as well as the analysis of the causal relation of spirituality with organizational variables such as motivation, stress, earnings, leadership style, setting purposes, the decision making process, productivity, absenteeism, turnover, organizational performance, share prices but also personal variables such as peace, joy..."(Nicolae, 2013: 559);

- A plea is made for management scholars to use: "...non-positivist research methods, such as ethnomethodological and other qualitative techniques." (Nicolae, 2013: 562).

- A common distinction in the field is to distinguish between two levels in studying and writing about workplace spirituality, namely, the personal (or individual) and the organizational. The former is concerned about the spiritual well-being of employees in the work situation, the latter about how spirituality affects the productivity and success of organizations. (Garcia-Zamor, 2003: 360 and 362).

\subsection{Workplace spirituality and organizational performance}

Reviews and empirical findings indicate that:

- "There has been ample empirical evidence that spirituality in the workplace creates a new organizational culture in which employees feel happier and perform better." (Garcia-Zamor, 2003: 362);

- Based on a review of 140 articles, one author identifies three different perspectives on the benefits of spirituality for both the worker and the organization, described as follows: "(a) Spirituality enhances employee well-being and quality of life; (b) Spirituality provides employees a sense of purpose and meaning at work; (c) Spirituality provides employees a sense of interconnectedness and community." (Karakas, 2010: 89);

- There is also a suggestion that: "...the concept of servant leadership can be enhanced by combining it with spiritual leadership." (Lynch, 2013: 87);

- "Spirituality can positively affect employee and organizational performance [through a] spirituality-based intuition [which] can also facilitate employees to develop a more purposeful and compelling organizational vision, [and] provide opportunities for employees to experience a higher sense of service and greater personal growth and development [as well as] enhance teamwork and employee commitment to the organization..." (Neck, 1994: 10); 


\section{The Theoretical Orientation in the Workplace Spirituality Field (Type I Paradigm)}

This section briefly points to some examples of a more purely theoretical (type I) inclination in the workplace spirituality field. Jurkiewics and Giacalone (2004: 129, 131) proposes a so-called values framework that may be empirically tested (see Figure 4 below)

Figure 4: A values framework of workplace spirituality

\begin{tabular}{|c|c|c|}
\hline$(+)$ & & $(-)$ \\
\hline $\begin{array}{l}\text { Kindness toward others and an orientation to promote the happiness } \\
\text { and prosperity of employees and other stakeholders within the work } \\
\text { context }\end{array}$ & Benevolence & $\begin{array}{l}\text { Employee feelings have no relevance in the work environment, their } \\
\text { happiness and prosperity are their own concern }\end{array}$ \\
\hline $\begin{array}{l}\text { Long-term focus, showing a concern for the consequences of one's } \\
\text { actions into the future; respectful of future generations }\end{array}$ & Generativity & $\begin{array}{l}\text { Concerned with immediate reward without regard for long-term } \\
\text { consequences }\end{array}$ \\
\hline $\begin{array}{l}\text { Practices and policies that assert the essential dignity and worth of } \\
\text { each employee; provides an opportunity for personal growth in } \\
\text { conjunction with organizational goals }\end{array}$ & Humanism & $\begin{array}{l}\text { Lacking mercy or kindness; cruel; impersonal, cold; unconcerned } \\
\text { with the needs of employees as human beings; lacking warmth or } \\
\text { geniality }\end{array}$ \\
\hline $\begin{array}{l}\text { Uncompromising adherence to a code of conduct; sincerity, honesty, } \\
\text { candor; exercising unforced power }\end{array}$ & Integrity & $\begin{array}{l}\text { Organizational members can act deceptive, expedient, artificial, } \\
\text { shallow, politically manipulative, and are inconsistent in following a } \\
\text { code of conduct }\end{array}$ \\
\hline $\begin{array}{l}\text { Even-handed treatment and judgment of employees; impartial, fair, } \\
\text { honest; unbiased assignment of rewards and punishments }\end{array}$ & Justice & Dishonest, faithless; wrongful or biased in judgments \\
\hline $\begin{array}{l}\text { All employees are interconnected and mutually dependent, each } \\
\text { contributes to the final output by working in conjunction with others }\end{array}$ & Mutuality & $\begin{array}{l}\text { Employees are separate and distinct free agents responsible for } \\
\text { their own output irrespective of others' efforts, time spent interacting } \\
\text { with others is dictated by necessity }\end{array}$ \\
\hline $\begin{array}{l}\text { Open-minded, flexible thinking, orientation toward calculated risk- } \\
\text { taking, rewards creativity }\end{array}$ & Receptivity & $\begin{array}{l}\text { Enforces one right way to do things, discourages questioning and } \\
\text { innovation; punishes behavior outside the norm. }\end{array}$ \\
\hline $\begin{array}{l}\text { Regard and treat employees with esteem and value; showing } \\
\text { consideration and concern for others }\end{array}$ & Respect & $\begin{array}{l}\text { Demonstrates disesteem and contempt for employees; uncivil, } \\
\text { discourteous to others }\end{array}$ \\
\hline $\begin{array}{l}\text { Independently follows through on goal attainment irrespective of } \\
\text { difficulty or obstacles; concerned with doing what's right rather than } \\
\text { the right thing }\end{array}$ & Responsibility & $\begin{array}{l}\text { Shirks work and follows through only insofar as forced to do so; } \\
\text { does not exert effort independent of external controls }\end{array}$ \\
\hline $\begin{array}{l}\text { Being able to confidently depend on the character and truth of the } \\
\text { organization and its representatives }\end{array}$ & Trust & $\begin{array}{l}\text { Character, truth, maintenance obligations and promises is at the } \\
\text { discretion of individual organizational members as predicated by } \\
\text { their personal gain }\end{array}$ \\
\hline
\end{tabular}

Marques, Dhiman and King (2005: 88) propose the following elements (and benefits) of a cyclical model for workplace spirituality, namely:

1. It incorporates various internal, integrated and external factors;

2. The individual holds: "...a set of internal values, which are honesty, creativeness, pro-activity, kindness, dependability, confidence and courage. This set of values typifies the worker that performs at his or her highest level of spiritual awareness";

3. Based on the individual's spiritual consciousness and internal values, the worker: "...realizes his or her interconnectedness with the work environment";

4. It is important the workplace environment be aesthetically and motivationally enhanced;

5. "In a workplace that nurtures the spiritual mindset, and where workers realize the value of interconnectedness and an aesthetically motivational environment, team performance and harmony should be practiced";

6. This should allow the organization to: "...perform well, and may become a leader in its industry and community";

7. This will allow the organization to: "...maintain its leadership through performances of fairness, cooperativeness, vision, responsibility, charity, creativeness, high productivity and accomplishment";

8. In turn, the afore-mentioned will help the organization realize and recognize: "...the value and input of its workforce and do everything to maintain this workforce by increasing job satisfaction and self-esteem within the workers";

9. Which, again, should: "...encourage the spiritual mindset within its workers, consisting of values such as honesty, creativeness, pro-activity, kindness, dependability, confidence and courage," thus completing a positive or virtuous cycle.

Miller and Timothy (2010) proposes a so-called The Integration Box (TIB) theory: "... as a means to understand and potentially evaluate how individuals integrate faith and work, as well as a means for organizations to understand, and 
respond constructively to the phenomena of religious values in the workplace" (Miller et al, 2010: 49). Figure 5 (adopted from Miller et al, 2010: 54, Table 1) describes elements of what is referred to as the 'Four E's or manifestations' of the TIB theory, namely, Ethics, Expression, Experience and Enrichment.

Figure 5: Description of the manifestations and their corresponding motivations

\begin{tabular}{|l|l|l|}
\hline Manifestation & Description & Motivation \\
\hline Ethics Type & $\begin{array}{l}\text { Places high value on attention to ethical } \\
\text { concerns. }\end{array}$ & $\begin{array}{l}\text { One's faith/spirituality: guides one; compels one; } \\
\text { and/or inspires one to take ethical actions. }\end{array}$ \\
\hline Expression Type & $\begin{array}{l}\text { Places high value on the ability to express } \\
\text { their faith tradition and worldview to others. }\end{array}$ & $\begin{array}{l}\text { Persuading others to join their faith tradition or } \\
\text { worldview, as a response to religious obligation or } \\
\text { freedom of expression. }\end{array}$ \\
\hline Experience Type & $\begin{array}{l}\text { Places high value on how they experience } \\
\text { their work, often understanding it as a spiritual } \\
\text { calling and having special meaning }\end{array}$ & $\begin{array}{l}\text { A search for meaning in their work; purpose for } \\
\text { their work; and value in the work itself. }\end{array}$ \\
\hline Enrichment Type & $\begin{array}{l}\text { Places high value on drawing strength and } \\
\text { comfort from spiritual and/or consciousness } \\
\text { practices. }\end{array}$ & $\begin{array}{l}\text { Draws strength and comfort for work; coping with } \\
\text { pressures and problems at work; and finding } \\
\text { wisdom and personal growth through work. }\end{array}$ \\
\hline
\end{tabular}

In answer to the question '....what effects do organizations with a greater spiritual emphasis have upon employee or worker outcomes?' Shinde (2010: 123) provides a conceptual scheme, shown in Figure 6 below.

Figure 6: A comparison of spiritual and secular organization

\begin{tabular}{|l|l|}
\hline & Outcomes \\
\cline { 2 - 2 } & Job involvement \\
\hline Spiritually committed organization $(+)$ & Job satisfaction \\
\hline Spiritually neutral organization $(-)$ & Commitment \\
\hline & Deviance \\
\cline { 2 - 2 } & Job stress \\
\cline { 2 - 2 } & Employee spirituality \\
\cline { 2 - 2 } & Job performance \\
\hline
\end{tabular}

In turn, Hayden and Barbuto (2011: 143) offer the following model for a 'non-ideological' conception of workplace spirituality (see Figure 7 below).

Figure 7: Anchors of conceptual characterizations of spirituality

\begin{tabular}{|c|c|}
\hline Prescriptive & Descriptive \\
\hline Religious & Secular \\
\hline Exclusive & Inclusive \\
\hline Limited & Universal \\
\hline Closed & Open \\
\hline Spirit & spirit \\
\hline Ideological & Non-ideological \\
\hline Exploratory & Consequential \\
\hline Contextual & Acontextual \\
\hline
\end{tabular}

Lastly, Phipps (2012: 177) suggests a cognitive framework that describes: "... how the personal spiritual beliefs of a top level leader operate in strategic decision making like a schema to filter and frame information."

\section{The Empirical Orientation in the Workplace Spirituality Field (Type II Paradigm)}

This section offers a few examples of the empirical orientation, namely, of the scientific (hypothesis-testing) approach in the workplace spirituality field, an approach which is common to human sciences research, generally. These are conveniently summarized in Figure 8 below. 
Figure 8: Examples of the empirical (type II) approach in workplace spirituality research

\begin{tabular}{|c|c|}
\hline Author (s) & Description \\
\hline Mitroff and Denton (1999) & $\begin{array}{l}\text { A series of questionnaire }(n=2000) \text { and interview studies of senior executives on 'what gave them } \\
\text { meaning and purpose in their work and in their lives.' }\end{array}$ \\
\hline Moore and Casper (2006) & $\begin{array}{l}\text { A study of } 228 \text { managers and professionals in } 14 \text { different industries, to establish the relationship } \\
\text { between workplace spirituality, perceived organizational support, affective organizational } \\
\text { commitment and intrinsic job satisfaction. }\end{array}$ \\
\hline $\begin{array}{l}\text { Kolodinsky, Giacalone \& Jurkiewics } \\
\text { (2008). }\end{array}$ & $\begin{array}{l}\text { Using } 5 \text { samples of workers doing graduate studies to investigate the relationship between } \\
\text { workplace spirituality and job involvement, organizational identification, rewards satisfaction, and } \\
\text { organizational frustration }\end{array}$ \\
\hline $\begin{array}{l}\text { Fawcett, Brau, Rhoads, Whitlark, \& } \\
\text { Fawcett (2008) }\end{array}$ & $\begin{array}{l}\text { A study of a sample of } 350 \text { customer service representative 'to explore the relationship between } \\
\text { workplace attributes, organizational climate, and personal values. Affirmation, belonging, and } \\
\text { competence emerge as critical elements of a people-centered, inspiring organizational culture.' }\end{array}$ \\
\hline Petchsawang \& Duchon (2009 & $\begin{array}{l}\text { A factor-analytic questionnaire study of } 250 \text { Thai employees that 'suggests a four-factor model: } \\
\text { compassion, meaningful work, mindfulness and transcendence' }\end{array}$ \\
\hline Ahiauzu, 2010 & $\begin{array}{l}\text { Study of a sample of } 235 \text { middle and senior managers in the Nigerian manufacturing industry, } \\
\text { examining the relationship between 'altruistic love' as an element in the emerging theme of } \\
\text { 'workplace spirituality', and 'workers' commitment.' }\end{array}$ \\
\hline Altaf \& Awan, 2011 & $\begin{array}{l}\text { A questionnaire study of a sample of } 76 \text { respondents on the 'moderating affects of workplace } \\
\text { spirituality on job overload and employee's satisfaction relationship.' }\end{array}$ \\
\hline Marschke, Preziosi \& Harrington (2011). & $\begin{array}{l}\text { A study of } 120 \text { sales managers in the USA on job satisfaction and its relationship to spirituality in } \\
\text { the workplace. }\end{array}$ \\
\hline Mat Desa, \& Koh Pin Pin (2011). & $\begin{array}{l}\text { A Malaysian study ( } n=153 \text { public accountants/auditors) on the influence of four aspects of } \\
\text { workplace spirituality (a team's sense of community, alignment between organizational and } \\
\text { individual values, sense of contribution to society and enjoyment at work) on affective } \\
\text { commitment. }\end{array}$ \\
\hline Chen \& Yang (2012). & $\begin{array}{l}\text { Using a sample of } n=466 \text { (from } 28 \text { retail companies), the study investigates the relationship } \\
\text { between spiritual leadership and organizational citizenship behaviour. }\end{array}$ \\
\hline Nasurdin, Nejati \& Mei (2013). & $\begin{array}{l}\text { An analysis academic staff in } 15 \text { Malaysian institutions of higher education } \\
(n=171) \text { on the effects of workplace spirituality on organization citizenship behavior, with gender } \\
\text { as moderating variable. }\end{array}$ \\
\hline
\end{tabular}

\section{The Narrative Orientation in the Workplace Spirituality Field (Type III Paradigm)}

This section briefly surveys the approaches of workplace spirituality scholars writing in the narrative-interpretive (qualitative research) tradition (type III meta-orientation). Figure 9 provides a brief overview.

Figure 9: Examples of workplace spirituality contributions in the narrative tradition (Type III)

\begin{tabular}{|l|l|}
\hline Author (s) & Description \\
\hline $\begin{array}{l}\text { Driscoll, \& McKee } \\
\text { (2007). }\end{array}$ & $\begin{array}{l}\text { Discusses the relationship between the literatures of organizational storytelling, spirituality in the } \\
\text { workplace, organizational culture, and authentic leadership. }\end{array}$ \\
\hline Bell, (2008). & $\begin{array}{l}\text { The author discusses spirituality as a force of resistance in relation to management 'through the } \\
\text { development of a practice-based morality.' }\end{array}$ \\
\hline $\begin{array}{l}\text { Brooke, \& Parker } \\
(2009) .\end{array}$ & $\begin{array}{l}\text { A critical view of the workplace spirituality field 'with a special emphasis on the issues it raises for the } \\
\text { researcher.' }\end{array}$ \\
\hline Nur, (2009). & $\begin{array}{l}\text { Narrates a Christian form of leadership that reflects 'deep spirituality, consistency, fairness, } \\
\text { prayerfulness, genuineness, humbleness, and intentionality,' as well as leading by example. }\end{array}$ \\
\hline Gross, (2010). & $\begin{array}{l}\text { Reports a single organization case study identifying three aspects in which 'workplace spirituality can } \\
\text { be misused: to mislead members about the nature of their work, about what an organization can offer } \\
\text { to its members and about the societal value of an organization.' }\end{array}$ \\
\hline
\end{tabular}

\section{The Pragmatic Orientation in the Workplace Spirituality Field (Type IV Paradigm)}

This section briefly covers ways of promoting, developing and managing spirituality in the workplace. It is about workplace spirituality policies and practices in work organizations, and therefore reflects the pragmatic (type IV) metaorientation in the field. Figure 10 provide a few examples of this paradigm. 
Figure 10: Examples of the pragmatic orientation (type IV) in the workplace spirituality field

\begin{tabular}{|l|l|}
\hline $\begin{array}{l}\text { Neck, \& Milliman, } \\
\text { (1994). }\end{array}$ & $\begin{array}{l}\text { Proposes though self-leadership (TSL) as an approach to 'assist employees in influencing or } \\
\text { leading themselves towards experiencing more spirituality in their organizational life.' }\end{array}$ \\
\hline Marques, (2005). & $\begin{array}{l}\text { Offers perspectives on spirituality in the workplace, as well as various means in which HR } \\
\text { management can create and maintain a spiritual work environment that promotes lasting } \\
\text { organizational performance. }\end{array}$ \\
\hline McCarthy, (2007). & $\begin{array}{l}\text { Discusses various risks associated with as well as strategies to effectively manage prayer in the } \\
\text { workplace. }\end{array}$ \\
\hline $\begin{array}{l}\text { Bygrave, \& } \\
\text { Macmillan (2008 }\end{array}$ & $\begin{array}{l}\text { Proposes the European (more humane) Dream, as opposed to the American (materialistic) Dream } \\
\text { as approach for the workplace spirituality movement. }\end{array}$ \\
\hline $\begin{array}{l}\text { Fry, \& Cohen } \\
\text { (2009). }\end{array}$ & $\begin{array}{l}\text { Recommends the paradigm of spiritual leadership for organizational transformation and recovery } \\
\text { from the negative aspects of extended work hours cultures, to the benefit of both worker well- } \\
\text { being and organizational profitability. }\end{array}$ \\
\hline $\begin{array}{l}\text { Gross-Schaefer, } \\
(2009) .\end{array}$ & $\begin{array}{l}\text { Highlights various tools work organizations can follow, that will increase the awareness of and } \\
\text { focus on spirituality in the work environment. }\end{array}$ \\
\hline Kim, (2009). & Promotes the doctrines of 'great spiritual teachings' for addressing spirituality in the workplace. \\
\hline Pawar, (2009). & $\begin{array}{l}\text { Proposes a comprehensive model (which includes a leadership, group, as well as organizational } \\
\text { focus) for facilitating the development of spirituality in the workplace. }\end{array}$ \\
\hline
\end{tabular}

\section{Conclusion}

A meta-theory that was previously developed brought together implicit premises or world views that constantly re-surface in human thought. Subsequently, four paradigmatic or root intellectual orientations (designated as type I, type II, type III and type IV) have been identified.

The theory was found to be applicable across a wide range of thinkers, scholarly disciplines, and cultures. In the present case the workplace spirituality literature is analyzed using this framework. Four basic paradigms in the workplace spirituality scholarship are identified and briefly described in terms of a survey of various examples of each meta-type: the theoretical (type I), the empirical (type II), the narrative-interpretive (type III), and the pragmatic (type IV).

\section{References}

Ahiauzu, A. (2010). Altruistic love culture and workers' commitment in the Nigerian manufacturing industry: A study in workplace spirituality. Journal of Management Policy and Practice, 11, 5, 97 - 105.

Altaf, A. \& M. A. Awan (2011). Moderating effect of workplace spirituality on the relationship of job overload and job satisfaction. Journal of Business Ethics, 104, 93-99.

Bell, E. (2008). Towards a critical spirituality of organization. Culture and Organization, 14, 3, 293-307.

Brooke, C. \& Parker, S. (2009). Researching spirituality and meaning in the workplace. The Electronic Journal of Business Research Methods, 7, 1, 1- 10.

Bygrave, C. \& S. Macmillan (2008). Spirituality in the workplace: A wake-up call from the American dream. Journal of Workplace Rights, $13,1,93-112$.

Chen, C-Y \& C-F. Yang (2012). The impact of spiritual leadership on organizational citizenship behavior: A multi-sample analysis, Journal of Business Ethics, 105, 107-114.

Driscoll, C. \& M. McKee (2007). Restorying a culture of ethical and spiritual values: A role for leader storytelling. Journal of Business Ethics, 73, 205-217.

Fawcett, S. E., Brau, J. C., Rhoads, G. K., Whitlark, D \& M. Fawcett (2008). Spirituality and organizational culture: Cultivating the ABCs of an inspiring workplace. International Journal of Public Administration, 31, 420-438.

Fry, L. W. \& M. Cohen (2009). Spiritual leadership as a paradigm for organizational transformation and recovery from extended work hours cultures. Journal of Business Ethics, 84, 265-278.

Garcia-Zamor, Jean-Claude (2003). Workplace spirituality and organizational performance. Public Administration Review, 63, 3, 355 363

Gross, C. (2010). Spiritual cleansing: A case study on how spirituality can be mis/used by a company. Management Revue, 21, 1, 60-81.

Gross-Schaefer, A. (2009). Reaching for the stars: Effective tools for the creation of a more spiritual workplace. Employee Relations Law Journal, $35,1,25-42$.

Hayden, R. W. \& J. E. Barbuto (2011). Expanding a framework for a non-ideological conceptualization of spirituality in the workplace. Institute of Behavioral and Applied Management, 142 - 155.

Inglehart, R. (2000). Globalization and Postmodern values. The Washington Quarterly, 23, (1), 215 - 228.

Jurkiewics, C. L. \& R. A. Giacalone (2004). A values framework for measuring the impact of workplace spirituality on organizational 
performance. Journal of Business Ethics, 49, 129-142.

Karakas, F. (2010). Spirituality and performance in organizations: A literature review. Journal of Business Ethics, 94, 89-106

Kim, L. (2009). Improving the workplace with spirituality $1+1=5$. The Journal for Quality and Participation, 32 - 35

Kolodinsky, R. W., R. A. Giacalone \& C. L. Jurkiewics (2008). Workplace values and outcomes: Exploring personal, organizational, and interactive workplace spirituality. Journal of Business Ethics, 81, 465-480.

Lynch, J. A. \& H. H. Friedman (2013). Servant leader, spiritual leader: The case for convergence. Journal of Leadership, Accountability and Ethics, 10 (2), 87 - 95

Marques, J. (2005). HR's crucial Role in the establishment of spirituality in the workplace. The Journal of American Academy of Business, 7, 2, $27-31$.

Marques, J., S. Dhiman \& R. King (2005). Spirituality in the workplace: Developing an integral model and a comprehensive definition. The Journal of American Academy of Business, Cambridge, 7, 1, 81-91.

Marschke, E., R. Preziosi \& W. J. Harrington (2011). How sales personnel view the relationship between job satisfaction and spirituality in the workplace. Journal of Organizational Culture, Communications and Conflict, 15, 2, 71 - 110.

Mat Desa, N \& D. Koh Pin Pin (2011). The workplace spirituality and affective commitment among auditors in big four public accounting firms: does it matter? Journal of Global Management, 2, (2), 216 - 226.

McCarthy, W. B. (2007). Prayer in the workplace: Risks and strategies to manage them. The Business Renaissance Quarterly: Enhancing the Quality of Life at Work, $97-105$.

Miller, D. W. \& E, Timothy (2010). Rethinking the impact of religion on business values: understanding its re-emergence and measuring its manifestations. Journal of International Business Ethics, 3, 2, $49-57$.

Moore, T. W. \& W. J. Casper (2006). An examination of proxy measures of workplace spirituality: A profile model of multidimensional constructs. Journal of Leadership and Organizational Studies, 12, 4, 109 - 118.

Mitroff, I.I \& Denton, E.A. (1999). A study of spirituality in the workplace. Sloan Management Review, 40, (4), 83 - 93.

Nasurdin, A. M., M. Nejati \& Y. K. Mei (2013). Workplace spirituality and organizational citizenship behaviour: Exploring gender as a moderator. South African Journal of Business Management. 44, I, 61 - 74.

Neck, C.P \& Milliman, J.F. (1994). Thought self-leadership finding spiritual fulfillment in organizational life. Journal of Managerial Psychology, 9, (6), 15 - 21.

Nicolae, M., Ion, I \& E. Nicolae (2013). The research agenda of spiritual leadership. Where do we stand? Review of International Comparative Management, 14, 4, 551-566.

Nur, Y. A. (2009). Business as mission: The spirit of leadership. The Business Renaissance Quarterly: Enhancing the Quality of Life at Work, 45- 62.

Pawar, B. S. (2009). Workplace spirituality facilitation: A comprehensive model. Journal of Business Ethics, 90, 375-386.

Petchsawang, P \& D. Duchon (2009). Measuring workplace spirituality in an Asian context. Human Resource Development International, $12,4,459-468$.

Phipps, K. A. (2012). Spirituality and strategic leadership: The influence of spiritual beliefs on strategic decision making. Journal of Business Ethics, 106, 177-189.

Pietersen, H. J. (2011). The Four Types of Knowing -Metaphysical, Scientific, Narrative and Pragmatic: A Meta-Epistemology of Mind, New York: Edwin Mellen Press.

Pietersen, H. J. (2014). The Four Archetypal Orientations of the Mind: Foundational. Experiential, Organizational and Actional, New York: Edwin Mellen Press.

Poe, R \& Courter, C.L. (1995). Spirituality at work. Across the Board, 32, (10), 5.

Shinde, U. S. (2010). The impact of organizational spirituality on employee outcomes. International Journal of the Academic Business World, 4, 2, $123-130$. 